\title{
Diagnosis and Treatment of Alar Rim Deformities
}

\author{
Ji-Eun Lee and Ji Yun Choi \\ Department of Otorhinolaryngology-Head and Neck Surgery, College of Medicine, Chosun University, Gwangju, Korea
}

\section{콧날개 변형의 진단 및 치료}

\author{
이 지 은 최 지 윤 \\ 조선대학교 의학전문대학원 이비인후과학교실
}

\author{
Received February 27, 2015 \\ Revised July 28, 2015 \\ Accepted July 31, 2015 \\ Address for correspondence \\ Ji Yun Choi, MD, PhD \\ Department of Otorhinolaryngology- \\ Head and Neck Surgery, \\ College of Medicine, \\ Chosun University, \\ 365 Pilmun-daero, Dong-gu, \\ Gwangju 61452, Korea \\ Tel $+82-62-220-3200$ \\ Fax $+82-62-225-2702$ \\ E-mail happyent@naver.com
}

\begin{abstract}
Alar rim deformity is one of the most challenging problems to correct in nasal surgery. It is difficult to correct, recurs easily, and needs delicate handling. The technique to correct a hanging alar includes excision a vestibular skin, direct skin excision, and/or excision of the lateral crus. The technique to correct the minimal-to-mild alar retraction includes scar contracture release, alar rim grafts, V-Y advancement flap and composite grafts. In case of severely retracted alar, several techniques such as lateral crural strut graft, alar spreader graft, inter-cartilaginous graft, and island pedicled advancement flap of the nasal dorsum can help to correct the deformities. Alar rotation flap, septal extension graft, alar base surgery, and derotation graft also have some benefit. Korean J Otorhinolaryngol-Head Neck Surg 2016;59(1):9-14
\end{abstract}

Key Words Alar rim deformities · Alar rim retraction · Rhinoplasty.

\section{서 론}

콧날개 변형(alar rim deformities)은 수술에 의해 이차적 으로 발행하는 경우가 대부분이지만 콧날개 모양에 대한 일 반인들의 관심이 많아짐에 따라 선천적으로 콧날개가 함몰 되거나 늘어져 있는 경우, 이를 교정하길 원하는 경우도 늘어 나고 있다. 콧날개 변형은 변형의 상태나 정도에 따라 수술방 법에 차이가 많이 있고, 적절한 술식의 선택이 어렵기 때문에 수술 전 분석이 매우 중요하다. 코 성형수술 전 반드시 콧날 개의 비대칭이나 변형이 있는지 확인하여 수술 후 콧날개 변 형이 악화될 수 있음을 환자에게 미리 알려주어야 한다. 콧 날개 변형의 악화가 가능한 경우에는 연골의 절제를 삼가고 연부조직에 손상을 가하지 않아야 하며, 과도한 코의 연장을 피하고 필요한 경우 하비익 연골(lower lateral cartilage)의 강 화 및 재배치가 필요하다. 또한 수술 전 이미 콧날개 변형이 심 한 경우, 환자와 충분한 상의를 거쳐 교정 술식이 까다롭고 개 선에 한계가 있으며 결과를 예측하기 어려운 점 등을 이해하 도록 해야 한다. 콧날개 변형의 교정은 미용적 개선뿐만 아니
라 외 비밸부(external nasal valve)의 약화로 인한 코막힘을 개선하는 데에도 효과적이다. 최근 코성형 및 재수술의 증가 로 인해 콧날개 변형이 많아지는 실정이므로 문헌고찰을 통 해 콧날개 변형의 진단 및 치료에 대해 살펴보고자 한다.

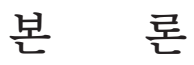

\section{콧날개 변형의 분류(Classification of alar rim} deformities)

Gunter 등은 콧날개와 비주의 상관관계를 분류하여 코 를 외측에서 보았을 때 타원형 콧구멍의 장축과 콧날개 또는 비주와의 거리가 정상적으로 1 2 $\mathrm{mm}$ 사이에 위치한다고 하 였다. 콧날개 함몰(alar retraction)은 외측에서 보았을 때 장 축과 콧날개 사이의 거리가 $2 \mathrm{~mm}$ 이상 떨어져 보이는 경우이 며, 콧날개 늘어짐(hanging alar)은 장축과 콧날개 사이의 거 리가 1 2 mm 이하로 나타난다. 비주의 퇴축(retracted columella)은 장축과 비주 사이의 거리가 1 2 $\mathrm{mm}$ 이하이고, 비 주의 늘어짐(hanging columella)은 장축과 비주 사이의 거리 


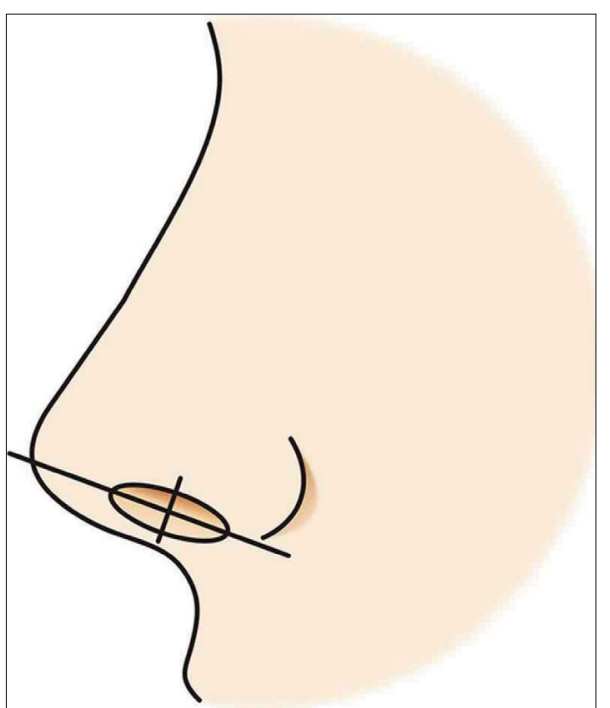

Fig. 1. The normal alar-columellar relationship (Adopted from Gunter JP, et al. Plast Reconstr Surg 1996;97(3):163-8). ${ }^{1)}$

가 $2 \mathrm{~mm}$ 이상으로 나타난다(Fig. 1).

최근 이식물의 사용 및 재수술의 증가에 따라 콧날개 피부 의 수축에 따른 다양한 콧날개의 변형이 보고되고 있다. Kim 등은 외측에서 관찰이 힘든 다양한 형태의 alar notching을 정면에서 보이는 위치에 따라 3 개의 형태(내측, 중앙, 외측)로 분류하였다. 이 분류는 특히 동양인에 있어서 콧날개 함몰의 원인을 파악하고 적절한 교정술식을 결정하는 데 도움이 된 다. 내측이나 중앙에 위치한 alar notching은 반흔 구축, 과도 한 절제, 적절하지 못한 봉합법에 의한 하비익 연골의 과도한 내측 이동이 주된 원인으로 동양인에 있어서 비중격 연장술 (septal extension graft)에 의해 악화되는 경향을 보인다. 이러 한 경우 콧날개 펼침 이식(alar spreader graft), 콧날개 역회 전이식(alar derotation graft) 등으로 하비익 연골을 원래의 위치 또는 외측으로 이동시켜 줌으로써 자연스러운 콧날개의 형태로 함몰의 교정이 가능하다. 외측의 alar notching은 대부 분 선천성 원인으로 연부조직의 결손이나 결핍이 주된 원인 이며 정도에 따라 이개 복합이식(auricular composite graft), 하비익 연골 지주이식(lateral crural strut graft), 콧날개 연 장이식술(alar extension graft) 등의 구조적인 지지와 함께 피판술 등을 통한 주변의 피부 보충이 필요하다.2)

\section{콧날개 늘어짐의 교정(Treatment of hanging alar)}

가장 흔히 사용되는 방법은 전정피부(vestibular skin)를 타 원형으로 절제하여 봉합하는 술식이다. 절제되는 타원형 피 부는 콧날개에 평행하게 하여 교정을 원하는 범위보다 약간 큰 폭으로 절제한다. 그러나 너무 과도하게 절제할 경우 콧날 개가 안으로 말려들어가 모양이 예쁘지 않으므로 $3 \mathrm{~mm}$ 이상

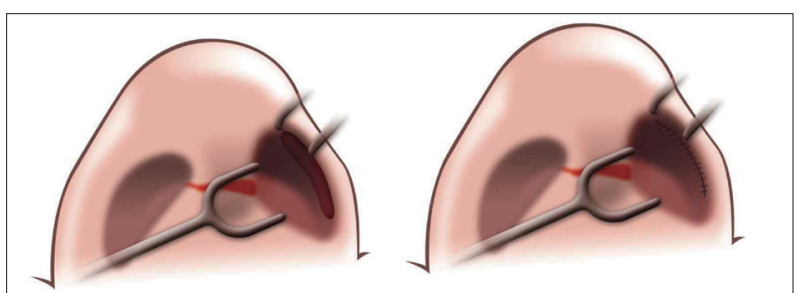

Fig. 2. Vestibular skin excision for correction of hanging alar. Elliptical skin excision from the vestibular area and closure with interrupted stitches using 5-0 Vicryl.

절제하지 않는 것이 좋다. ${ }^{1)}$ 피부가 두껍거나 딱딱한 경우에는 늘어진 피부를 직접 절제하는 것이 가장 효과적이나 겉에서 흥터가 보일 가능성이 있으므로 주의한다. 또한 하비익 연골 의 아래쪽 경계부를 절제하는 방법도 가능하나, 콧날개의 함 몰이나 불균형을 예방하기 위해서는 보전적으로 절제하는 것이 좋다. 심한 늘어짐은 하비익 연골의 위쪽 경계부를 절제 하고 내측의 전정피부를 절제 후 외측의 피부를 동시에 절제 하면 좋은 결과를 기대해 볼 수 있다(Fig. 2). ${ }^{3)}$

\section{콧날개 함몰의 교정(Treatment of alar retraction)}

콧날개 함몰은 콧날개 변형 중 가장 흔하게 관찰되는 변형 으로 교정이 어렵고 쉽게 재발하므로 섬세하게 다뤄야 한다.) 주로 과도한 코성형의 부작용으로 발생하는 것으로 알려져 있으나 수술을 받지 않은 사람에게도 흔히 관찰된다. 미용상 의 문제 외에도 기능적으로 외 비밸부의 좁아짐을 동반하는 경우가 많고, 특히 동양인은 관상학적으로 재물이 새어 나간 다고 하여 교정을 원하는 경우가 종종 있다.

콧날개 함몰이 발생하는 가장 흔한 원인은 하비익 연골이 과도하게 상방으로 위치하거나 내측으로 이동한 경우, 혹은 콧날개 주변 연부조직이 부족한 경우이다. 서양인의 경우에 는 하비익 연골의 과도한 절제가 주된 원인이며, 동양인의 경 우에는 반흔 수축(scar contracture)이 가장 흔한 원인이나 이 식물의 삽입이나 비중격 연장술도 유발 원인이 된다.) 하비익 연골의 과도한 절제는 연골의 약화를 가져오고 결과적으로 연골의 상방 위축을 초래하므로, 이러한 변형을 예방하기 위 해서는 하비익 연골의 폭을 최소한 $7 \mathrm{~mm}$ 이상 남겨 지지 구조 로서의 구조적 강도를 유지하고 함몰을 예방할 수 있도록 하 는 것이 좋다.

오랜 기간에 걸쳐 콧날개 함몰 교정을 위한 다양한 방법들 이 소개되고 있는데, 비익연이식(alar rim graft), 하비익 연골 지주이식, 이개 복합이식, 연골간 이식(intercartilaginous grafts), 콧날개 연장이식(alar extension graft), $\mathrm{V}-\mathrm{Y}$ 전진 피판법 등 이 그것이다. 또한 코의 경첩부위의 박리, 이상구 인대의 분리, 하비익 연골의 내, 외측 이동 등도 콧날개 함몰의 교정을 위 해 연구되어 왔다. ${ }^{5-12)}$ 
경증-중등도 함몰(Mild to moderate alar retraction)

콧날개 함몰의 교정은 함몰 정도에 따라 방법이 다르며 피 부의 상태나 연골의 상태가 치료 방법을 결정하는 데 중요한 인자로 작용한다. 경한 콧날개 함몰은 주로 보전적인 술식이 사용되는데 반흔 제거술, 비익연 이식, $\mathrm{V}-\mathrm{Y}$ 전진 피판술, 이개 복합이식 등의 술식이 효과적인 것으로 알려져 있다.

비익연이식(Alar rim graft)

콧날개 함몰이 $2 \mathrm{~mm}$ 이하면서 무딘 경우 가장 간단한 교정 방법은 비익연이식이다. 폭이 약 2 3 mm, 길이가 약 10 15 $\mathrm{mm}$ 의 길고 반듯한 연골조각을 디자인 한 후, 15 번 메스를 이용해 콧날개 안쪽 전정피부에 수직으로 절개를 가한 후 날 카로운 가위를 이용해 피하에 터널을 만들고 연골편을 삽입 한다. 이식물은 비익연과 평행하게 비익연의 직상방의 연조 직 공간에 삽입하며, 5-0 흡수사를 이용해 봉합을 시행한다. 이 때 이식물의 길이는 변형부위보다 길어야 한다. 이렇게 함으 로서 콧날개 가장자리에 지지를 더해주어, 콧날개의 notching 을 반듯하게 만들고 콧날개 가장자리를 1 2 $\mathrm{mm}$ 아래로 이 동시켜 경한 콧날개 함몰의 교정한다. 이 술식은 일차 코 성 형술 또는 재수술을 시행할 때 하비익 연골이 약하여 함몰 의 가능성이 있는 경우 예방적으로 시행할 수 있다. 그러나 심 각한 비익의 반흔, 전정피부의 결손, 하비익 연골의 결손 등과 같은 심한 함몰의 경우에는 효과적이지 않다(Fig. 3).,11)

\section{$\mathrm{V}-\mathrm{Y}$ 전진 피판술(V-Y advancement flap)}

Guyuron $^{6}$ 은 V-Y 전진 피판법을 소개하였는데, 그 방법은 다음과 같다. 비전정 피부에 비익을 기저부로 하는 $\mathrm{V}$ 자 형태 의 절개를 가하고 절개선의 꼭지점을 연골간 절개선 부위까 지 연장시킨 후 피판을 들어올린다. 들어올린 피판을 비익 하연 방향으로 이동시켜 콧날개 함몰을 교정한 다음 절개선 을 Y자 형태로 봉합한다. 하비익 연골이 약한 경우 연골의 보강을 추가로 요한다. 봉합이 끝나면 볼스터 드레싱을 1 주

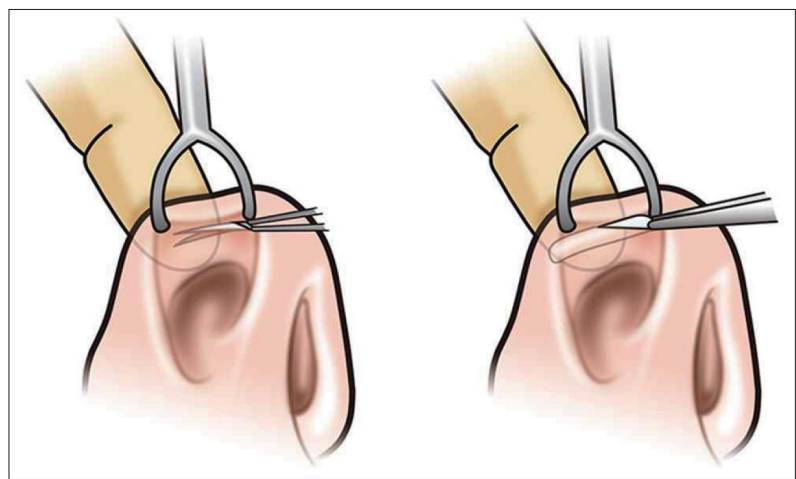

Fig. 3. Alar rim graft. Creation of a pocket along the alar rim using iris scissors and introduction of the graft into the pocket.
일간 유지한다(Fig. 4).

이개 복합이식(Composite alar rim graft)

이개 복합이식은 과거에 많이 사용하였던 방법으로, 피부 가 부드러워 잘 늘어나고 연골이 단단해야 좋은 결과를 얻을 수 있다. 먼저 이식할 부분의 만곡에 맞추어 이개 정(cymba concha) 또는 이개 강(cavum concha) 부위의 귀의 앞 또는 뒤에서 피부와 연골이 결합된 복합조직의 형태로 이식물을 채취한다. 이후 비익연 내측에 비익 연골의 하연을 따라 절개 를 가하여 피부를 벌려 포켓을 만든 다음, 포켓에 이식물을 삽입 후 연골은 연골끼리, 피부는 피부끼리 봉합한다. 이 방 법은 중등도 함몰의 교정에 주로 사용하며 그 외에도 비익연 높이의 비대칭, 또는 비공이나 비전정의 협착을 교정하는 데 에도 유용하게 쓰일 수 있다. 공여부는 대부분 일차 봉합이 가 능하나 여의치 않는 경우 이개 후방에서 피부이식을 해준다. 봉 합을 마친 후 볼스터 드레싱을 1주일간 유지한다(Fig. 5). ${ }^{7,11}$
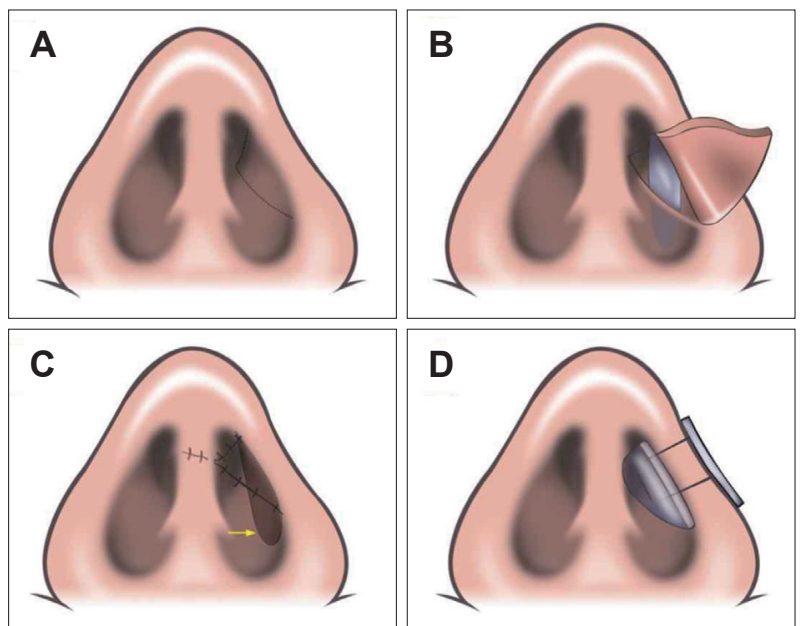

Fig. 4. $V-Y$ advancement flap (A). Design: the $V$ stars from the apex of nostril extends to the intercartilaginous line (B). The flap was undermined. A cartilage graft used for reinforcement of the lower lateral cartilage (arrow) (C). The flap was closed using $V$ to $Y$ fashion (D). The silastic splint was applied (Guyuron B. Plast Reconstr Surg 2001;107:859).

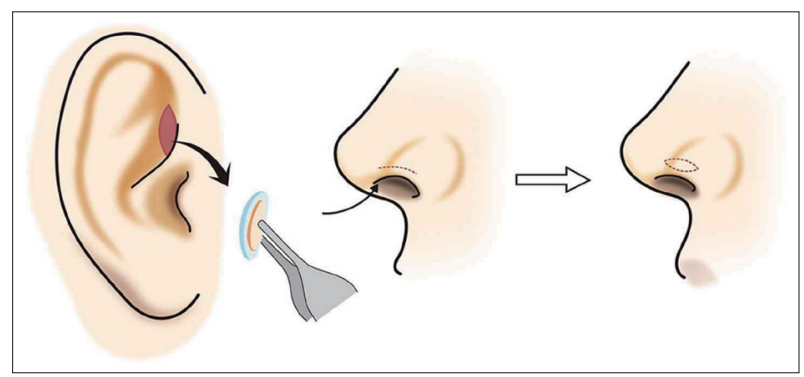

Fig. 5. Auricular composite graft. Harvesting of a composite skin and auricular cartilage graft and creation of a pocket and introduction of the graft into the pocket. 
심한 함몰의 교정(Severe alar retraction)

심한 콧날개의 함몰 교정은 비성형술에 있어서 가장 어려 운 수술 중 하나이다. ${ }^{1)}$ 콧날개 상방 이동은 콧날개의 변형 중 가장 흔하게 관찰되는 변형으로 교정을 위해서는 정확한 진 단을 요한다. 콧날개 함몰은 선천적으로 발생하기도 하지만 수술, 염증, 이물반응, 외상과 같은 이차적인 원인으로 인해 발생하는 경우가 더 흔하다. 콧날개 함몰의 기전은 하비익 연 골의 약화나 연골을 덮는 피부의 수축이 주된 원인으로, 경한 콧날개 함몰은 피부나 연조직의 탄성이 남아 있는 반면, 심 한 함몰은 피부의 구축으로 인해 탄력이 없는 딱딱한 피부 로 덮여 있는 경우가 많다. ${ }^{4}$ 경한 콧날개 함몰은 피부 밑 지지 구조의 변형만으로 교정이 가능하지만, 심한 함몰은 코안쪽 전정피부의 늘어짐과 지지 구조의 복원 또는 강화 및 재배치 뿐 아니라 피부의 보충이 필요하다. ${ }^{57)}$ 피부의 보충을 위해서 는 피부 밑 반흔을 최대한 제거하여 피부를 늘어나게 하고 추가적으로 피부가 필요한 경우에는 피판술을 이용한다.

비익연 지주 이식(Lateral crural strut graft)

비익연 지주 이식은 하비익 연골을 따라 연골 아랫면의 비 전정 피부를 박리하여 공간을 만든 후 길쭉한 형태의 이식물
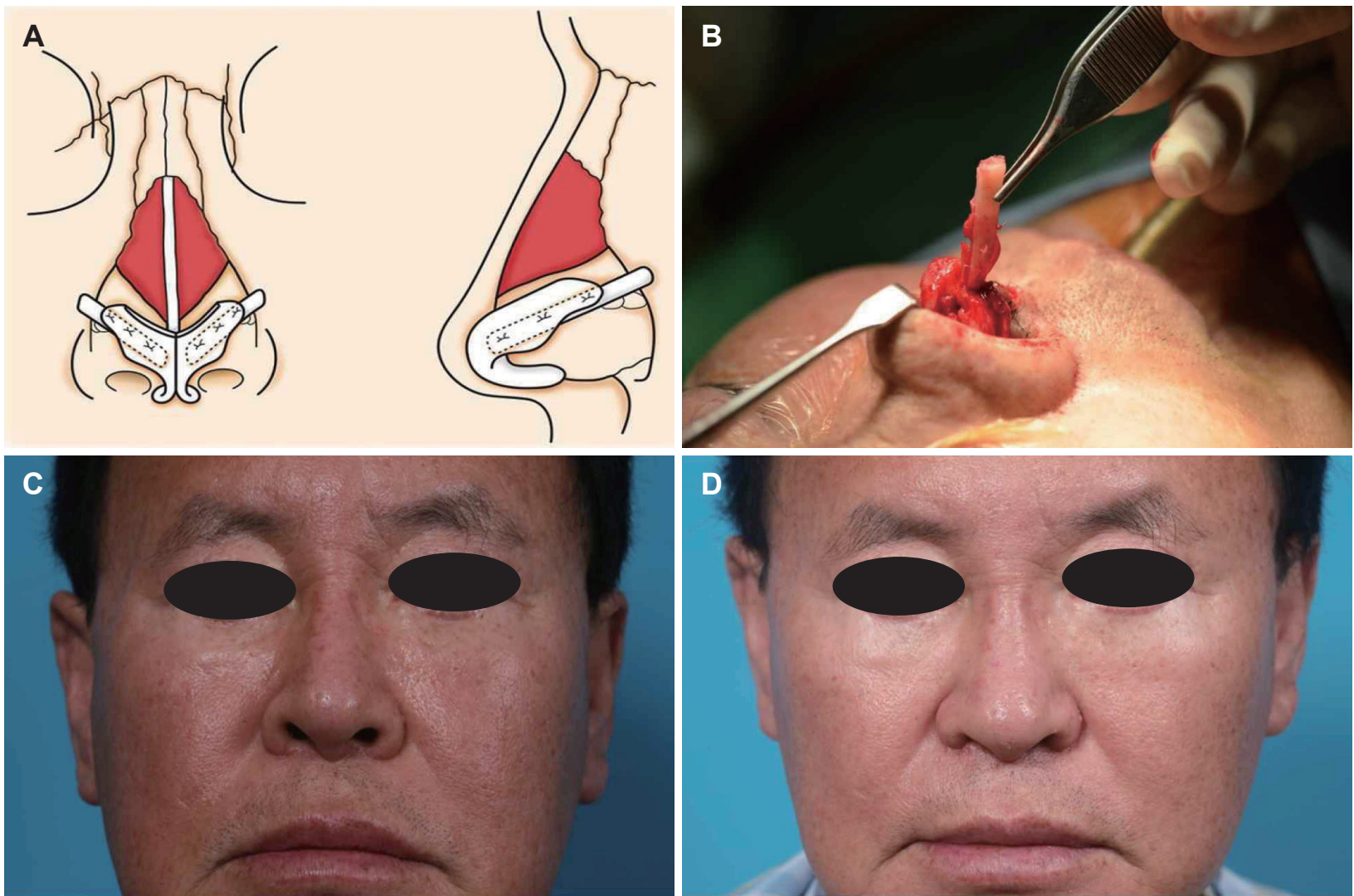

Fig. 6. The lateral crural strut graft. The graft is sutured to the under surface of the lateral crus (A). Intraoperative photo shows that strut graft attached to lower lateral cartilage using underlay fashion (B). Preoperative oblique photograph with alar retraction (C). Postoperative oblique photograph after 18 months of correction of alar retraction (D). 
로 이동하게 되면 콧등 중앙, 상비익 연골 상방, 하비익 연골 사이에 이식물을 삽입한 다음 하비익 연골을 외측으로 이동 시킨 후 고정-봉합한다. 이식물의 재료는 이개 연골이나 비중 격 연골이 적당하다. 콧날개 펼침 이식은 콧날개를 바깥쪽 아래쪽으로 이동시켜 콧날개 함몰의 근본적 원인을 교정해 준다. 재수술이 증가함에 따라 콧날개 확장이식은 구축이나 비중격 연장이식에 의한 콧날개 함몰을 교정하거나 들창, pinched nose의 교정에도 유용하게 쓰인다(Fig. 7). ${ }^{9)}$

연골간 이식(Intercartilaginous graft)

Gruber 등 ${ }^{10)}$ 은 상비익 연골과 하비익 연골 사이에 연골을 삽입하여 코의 외측부를 연장시키는 방법을 고안하였다. 연 골간 이식은 연조직을 충분히 늘여준 상태에서 아래쪽 지지 구조인 하비익 연골과 상비익 연골 사이에 연골을 삽입하여 콧날개를 아래쪽으로 연장시키는 방법이다. 이식물은 주로 비중격 연골이 사용되며 귀연골도 가능하다. 상비익 연골과 하 비익 연골 사이를 박리하여 비점막을 최대한 늘려주는 것이 이 술식의 핵심이며 주로 무딘 가위가 사용된다. 비점막이 찢 어지지 않도록 조심하면서 약 4 8 $\mathrm{mm}$ 의 공간을 확보한다. 연골의 봉합은 단단 봉합(end to end)으로 봉합 시에 연골이 꺾이는 것을 방지하기 위해 하비익 연골 상연 아래쪽에 이식 물을 겹쳐서 봉합한다(Fig. 8).

비배부 섬 전진 피판술(Island pedicled advancement flap of the nasal dorsum)

비배부에 삼각형 형태의 섬 피판을 디자인 후 피판을 비익 연 방향으로 전진시킨 다음 절개부를 $\mathrm{V}-\mathrm{Y}$ 형태로 봉합하는 수술방법이다. 삼각형의 아래쪽 경계는 비익구에 해당되고 옆면은 비배부와 비상악구(nasomaxillary groove)에 각각 평행하게 디자인한다. 안쪽으로는 비전정 피부를 충분히 늘 려주거나 이개 복합이식을 요한다. 이 술식의 핵심은 혈관의 손상 없이 섬 피판을 충분히 박리하여 비익연 방향으로 전진 시키는 것이며, 지지 구조가 약한 경우 연골의 강화를 통한 연골조직의 상부에 위치한 피판에 대한 충분한 지지가 중요 하다. 이 술식은 상대적으로 방법이 간단하고 정밀한 교정이 가능하며 공여부와 이식부의 피부색과 두께가 일치하여 수 술 후 결과가 좋을 뿐만 아니라 여러 단계의 수술이 필요하 지 않으며 비교적 결과의 예측이 가능하고 재발의 가능성이 적다는 장점이 있다. 그러나 비배부에 흉터가 생길 수 있어 심 한 피부의 수축이 있거나 흥터가 쉽게 생기는 환자, 혈액 공급 이 나쁘고 지지 구조가 약한 경우에는 적응증이 되지 않는다. 따라서 수술 전 흥터가 잘 생기는지, 전신적인 건강상태가 양 호한지, 담배를 피우는지 등을 확인하여야 한다 (Fig. 9). ${ }^{12)}$
일측의 연삼각(soft triangle)이 반흔으로 대치되거나 결손 된 경우 콧날개 회전 피판(alar rotation flap)을 고려해 볼 수 있다. 콧날개 회전 피판은 콧등의 피부로 turn in flap을 디자 인하여 연삼각 비전정 피부를 만들고 하비익 연골을 보강 후 콧등의 결손부위를 비익구를 따라 디자인한 회전 피판을 이

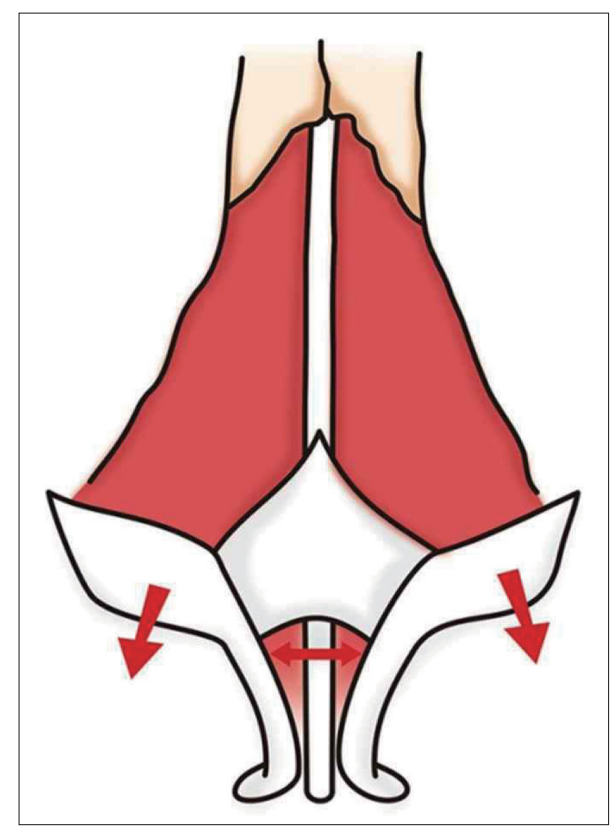

Fig. 7. Schematic diagram of the alar spreader graft. Complete release of the lateral crus which is spread by the alar spreader graft.

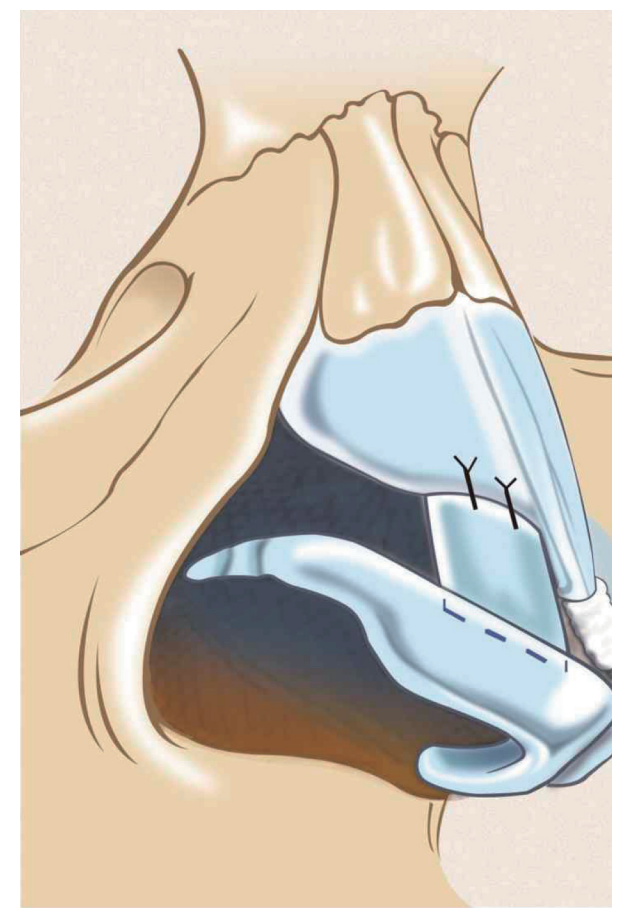

Fig. 8. Schematic diagram of the intercartilaginous graft. A septal graft is inserted between the upper lateral cartilage and the lower lateral cartilage (Adopted from Gruber RP, et al. Plast Reconstr Surg 2008;121(5):288e-96). ${ }^{10)}$ 


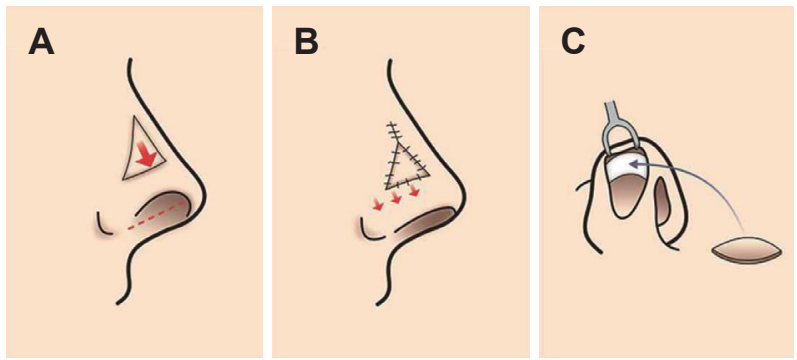

Fig. 9. The Island pedicled advancement flap of the nasal dorsum. Creation of the triangular island pedicled flap of the nasal dorsum (A). Closing in a V-Y fashion (B). Introduction of a composite auricular graft internally $(C)$.

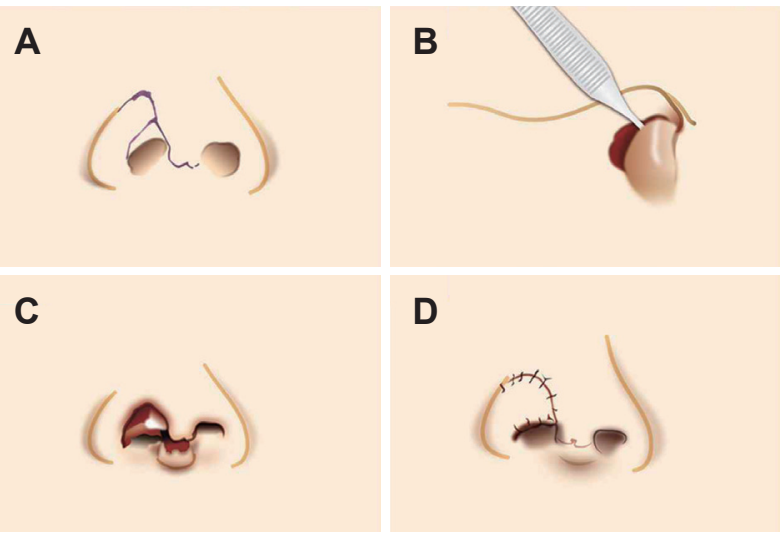

Fig. 10. The alar rotation flap. Design of alar rotation flap (A). Creation of alar rotation flap (B). Creation of intranasal mucosa using turn in flap (C). Rotation of the flap and closing the flap (D).

용해 덮어준다(Fig. 10). 양측 연삼각이 결손된 경우 양측의 콧날개 회전 피판을 이용하거나 결손이 심한 경우 전두 피판 (forehead flap)이 고려될 수 있다.")

위에서 소개한 수술방법과 더불어 비중격 연장술(septal extension graft), 코기저부 절제술(alar base resection), 역회 전 이식술(derotation graft) 등이 콧날개 함몰의 교정에 도움 을 준다. ${ }^{13,14)}$

\section{결 론}

콧날개 변형의 교정을 위해서는 콧날개 변형에 대한 주의 깊은 관찰이 필요하며 충분한 상담과 철저한 분석을 통해 원
인을 파악하고 변형의 정도, 피부의 상태를 고려하여야 한다. 콧날개 및 주변 조직의 정상적인 해부학적 구조를 잘 숙지하 고 적절한 피부의 유연성과 하비익 연골의 지지 구조를 제공 함으로써 미적, 기능적으로 정상적인 콧날개를 만들기 위해 적절한 수술방법을 선택하여 수술하여야 한다.

\section{Acknowledgments}

This work was supported by a grant from the Clinical Medicine Research Institute of the Chosun University Hospital (2014).

\section{REFERENCES}

1) Gunter JP, Rohrich RJ, Friedman RM. Classification and correction of alar-columellar discrepancies in rhinoplasty. Plast Reconstr Surg 1996;97(3):643-8.

2) Kim JH, Park SW, Oh WS, Lee JH. New classification for correction of alar retraction using the alar spreader graft. Aesthetic Plast Surg 2012;36(4):832-41.

3) McKinney P, Stalnecker ML. The hanging ala. Plast Reconstr Surg 1984;73(3):427-30.

4) Jung DH, Kwak ES, Kim HS. Correction of severe alar retraction with use of a cutaneous alar rotation flap. Plast Reconstr Surg 2009; 123(3):1088-95.

5) Rohrich RJ, Raniere J Jr, Ha RY. The alar contour graft: correction and prevention of alar rim deformities in rhinoplasty. Plast Reconstr Surg 2002;109(7):2495-505; discussion 2506-8

6) Guyuron B. Alar rim deformities. Plast Reconstr Surg 2001;107(3): 856-63.

7) Tardy ME Jr, Toriumi D. Alar retraction: composite graft correction. Facial Plast Surg 1989;6(2):101-7.

8) Gunter JP, Friedman RM. Lateral crural strut graft: technique and clinical applications in rhinoplasty. Plast Reconstr Surg 1997;99(4): 943-52; discussion 953-5.

9) Kim HS, Roh SG. The alar extension graft for retracted ala. J Korean Soc Plast Reconstr Surg 2009;36(1):66-74.

10) Gruber RP, Kryger G, Chang D. The intercartilaginous graft for actual and potential alar retraction. Plast Reconstr Surg 2008;121 (5):288e-96.

11) Kim DY, Kim IS, Jin HR. Frequently used grafts in Korean rhinoplasty: nomenclature and definitions. Korean J Otorhinolaryngol-Head Neck Surg 2010;53(7):412-8.

12) Choi JY, Javidnia H, Sykes JM. New techniques for correction of severe alar retraction using an island pedicled advancement flap of the nasal dorsum. J Plast Reconstr Aesthet Surg 2013;66(12):1803-4.

13) Guyuron B. Dynamics of rhinoplasty. Plast Reconstr Surg 1991; 88(6):970-8; discussion 979.

14) Paik MH, Chu LS. Correction of the short nose using derotation graft. Arch Aesthetic Plast Surg 2012;18(1):35-44. 